\title{
REVIEW
}

\section{Molecular imaging of rheumatoid arthritis: emerging markers, tools, and techniques}

\author{
Stéphanie Put ${ }^{1}$, René Westhovens ${ }^{2}$, Tony Lahoutte ${ }^{3,4}$ and Patrick Matthys ${ }^{1 *}$
}

\begin{abstract}
Early diagnosis and effective monitoring of rheumatoid arthritis (RA) are important for a positive outcome. Instant treatment often results in faster reduction of inflammation and, as a consequence, less structural damage. Anatomical imaging techniques have been in use for a long time, facilitating diagnosis and monitoring of RA. However, mere imaging of anatomical structures provides little information on the processes preceding changes in synovial tissue, cartilage, and bone. Molecular imaging might facilitate more effective diagnosis and monitoring in addition to providing new information on the disease pathogenesis. A limiting factor in the development of new molecular imaging techniques is the availability of suitable probes. Here, we review which cells and molecules can be targeted in the RA joint and discuss the advances that have been made in imaging of arthritis with a focus on such molecular targets as folate receptor, F4/80, macrophage mannose receptor, E-selectin, intercellular adhesion molecule-1, phosphatidylserine, and matrix metalloproteinases. In addition, we discuss a new tool that is being introduced in the field, namely the use of nanobodies as tracers. Finally, we describe additional molecules displaying specific features in joint inflammation and propose these as potential new molecular imaging targets, more specifically receptor activator of nuclear factor $\mathrm{kB}$ and its ligand, chemokine receptors, vascular cell adhesion molecule-1, av $\beta_{3}$ integrin, P2X7 receptor, suppression of tumorigenicity 2, dendritic cell-specific transmembrane protein, and osteoclast-stimulatory transmembrane protein.
\end{abstract}

\section{Introduction}

Anatomical imaging techniques have long been used to diagnose and monitor rheumatoid arthritis (RA). Over the past decade, these techniques have dramatically improved. For example, it is now possible to detect bone erosions within 6 to 8 weeks after arthritis onset. Nevertheless, pure anatomical imaging of even the earliest structural damage misses the preceding molecular, cellular, and physiological changes in the very early stages of RA pathogenesis. Molecular imaging, currently being developed in many domains of medical research and diagnostic practice, offers the possibility to visualize the early functional changes in RA [1]. This non-invasive technique allows early diagnosis, disease monitoring, guidance of treatment strategy, and possibly prediction of the outcome following the selected treatment. For example, patients can be selected for receiving a certain drug on the basis of the presence of the corresponding drug target, as was suggested for treatment of refractory

\footnotetext{
*Correspondence: patrick.matthys@rega.kuleuven.be

${ }^{1} \mathrm{KU}$ Leuven, Laboratory of Immunobiology, Rega Institute,

Minderbroedersstraat 10, 3000 Leuven, Belgium

Full list of author information is available at the end of the article
}

monoarthritis patients with TNF- $\alpha$ antagonists after imaging with ${ }^{99 \mathrm{~m}}$ technetium (Tc)-infliximab [2]. Some RA drugs are relatively expensive; hence, it is important to determine which patients may respond to a proposed therapy and which ones will not. Additionally, patients who are likely to develop a more severe disease can be identified and selected for more intensive treatment or more frequent monitoring. Molecular imaging of joint pathology both in human and in animal models of arthritis will improve our knowledge of the pathogenesis of the disease. In animals, imaging can be performed before and at different time points after the clinical onset of arthritis in the same animal with minimal perturbation of the experiment, and therefore more information can be obtained with fewer animals. Questions such as 'which are the earliest processes taking place in the pathogenesis of arthritis?' and 'which cells are most important in the disease process at which stage?' might become answered by live-animal imaging with specific probes. In addition, imaging of early-onset inflammation requires sensitive techniques characterized by limited background and non-specific signals.

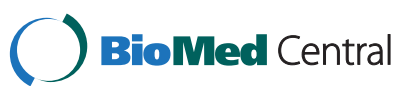

(c) 2014 Put et al.; licensee BioMed Central Ltd. The licensee has exclusive rights to distribute this article, in any medium, for 6 months following its publication. After this time, the article is available under the terms of the Creative Commons Attribution License (http://creativecommons.org/licenses/by/4.0), which permits unrestricted use, distribution, and reproduction in any medium, provided the original work is properly cited. 


\section{Review}

The pathogenesis of arthritis - which cells can we target? RA is a chronic autoimmune disease, affecting approximately $1 \%$ of the population worldwide. The disease is characterized by polyarthritis of the diarthrodial joints, primarily the small joints of hands and feet. A hallmark of RA is inflammation of the synovium (synovitis) with influx of mainly macrophages, T cells and B cells [3,4]. The synovial fluid is likewise enriched in immune cells, predominantly neutrophils [5] (Figure 1).

Macrophages are central effectors of synovial inflammation in RA and their abundance and degree of activation are correlated with disease severity [6]. Macrophages act through release of inflammatory factors, phagocytosis, and antigen presentation [4]. In RA, precursors from the monocyte/macrophage lineage are attracted from the blood to the inflamed joint and fuse to become active multinucleated osteoclasts, causing bone destruction.

$\mathrm{T}$ cells represent approximately $40 \%$ of immune cells in the synovial infiltrate of RA joints and have been implicated in different steps of RA pathology; they promote development of an autoimmune response and production of autoantibodies. Another role of T cells is the production of cytokines and induction of cytokine production by other cells [7]. B cells contribute to RA by the production of autoantibodies, antigen presentation, and T-cell activation [8]. They are indispensable for the development of arthritis as evident from the observation that the depletion of $\mathrm{B}$ cells abrogates the development of collagen-induced arthritis (CIA), an animal model for RA [9], and by the effectiveness of the B cell-depleting antibody, rituximab, that binds the CD20 surface molecule on B cells and inhibits the disease [10].

Synovial fibroblasts contribute to RA pathology by releasing matrix-degrading enzymes, including matrix metalloproteinases (MMPs) and cathepsins, which cause cartilage destruction [11]. Osteoblasts differentiate from mesenchymal stem cells and produce bone matrix. At their surface, these cells express receptor activator of nuclear factor-kappa-B ligand (RANKL), which is essential for osteoclast formation [12]. Blood vessel formation is elevated in RA joints and is associated with increased numbers of endothelial progenitor cells. Endothelial cells express cell adhesion molecules that facilitate rolling, binding, and transendothelial migration of leukocytes [13].

\section{The evolution of arthritis imaging} Anatomical imaging techniques

Conventional radiography is readily available, inexpensive, and reproducible. It allows the visualization of anatomical changes in established RA, such as erosions, joint space narrowing, and juxta-articular bone loss [14]. Ultrasonography (grey-scale imaging, power Doppler) has been in use for over 30 years. It can be routinely used in the clinic and was found to be more sensitive and accurate than clinical examination or conventional

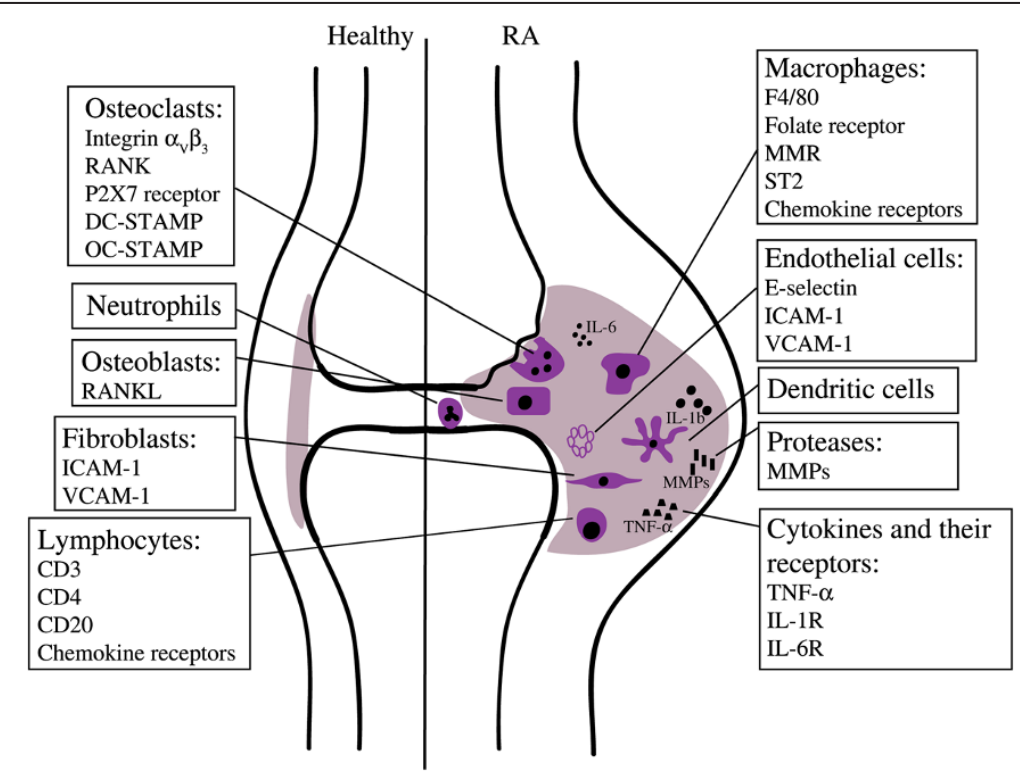

Figure 1 Schematic overview of specific cells and molecules that can be targeted in the rheumatic joint. The rheumatoid synovium is characterized by the influx of inflammatory cells and release of cytokines. Surface molecules that are expressed on these cells can be used as markers to target and visualize the different cell types in the inflamed joint. DC-STAMP, dendritic cell-specific transmembrane protein; ICAM-1, intercellular adhesion molecule-1; IL, interleukin; MMP, matrix metalloproteinase; MMR, macrophage mannose receptor; OC-STAMP, OSteoclaststimulatory transmembrane protein; RA, rheumatoid arthritis; RANK, receptor activator of nuclear factor-kappa-B; RANKL, receptor activator of nuclear factor-kappa-B ligand; ST2, suppression of tumorigenicity 2; TNF-a, tumor necrosis factor-alpha; VCAM-1, vascular cell adhesion molecule-1. 
radiography [15]. This technique provides information on bone degradation, synovitis, and inflammation of tendons and entheses. Since ultrasound cannot penetrate bone, osteitis cannot be detected [16]. Practical impediments are the lack of standard protocols for evaluation of RA and, therefore, strict dependence on the physician's skills. Hence, implementation studies in daily practice are still needed. When magnetic resonance imaging (MRI) was introduced, it soon became evident that this technique outperforms radiography in detecting early bone erosions [17,18]. MRI images are two- and threedimensional and have a higher contrast resolution, consequently soft tissues can be distinguished more efficiently. With MRI it is possible to detect synovial hyperplasia, bone changes, and cartilage degradation but also signs of RA in the pre-erosive phase [14]. It has now become the gold-standard modality for imaging synovitis in patients with early arthritis. Interestingly, several publications report accurate prediction of radiographic damage by MRI assessment of erosions or inflammation $[19,20]$. In a study of 42 patients with early RA, baseline MRI erosion scores could predict the development of erosions that became visible by radiography after 1 year. Absence of MRIdetectable erosions predicted the absence of erosions after this time period [21].

\section{Molecular imaging - state of the art}

Structural imaging techniques, though very useful, fail to provide information on the underlying biochemical processes. Therefore, novel imaging modalities using molecular probes such as optical imaging (bioluminescence, fluorescence, and near-infrared, or NIR; 600 to $750 \mathrm{~nm}$ ) or nuclear imaging (scintigraphy; positron emission tomography, or PET; and single-photon emission computed tomography, or SPECT) are currently being improved for arthritis imaging.

The term optical imaging encompasses techniques, such as bioluminescence and fluorescence, that use light as the primary imaging method. Bioluminescence enables visualization of biological processes in vivo. It is a powerful tool for preclinical imaging but less applicable in a clinical setting as it requires administration of foreign enzymes. Fluorescence imaging holds more promise for clinical applications, especially since the development of NIR probes that allow deeper penetration into tissues and less background interference. Nuclear imaging techniques, such as scintigraphy, PET, and SPECT, use markers that are labeled with radioisotopes. Radioactive tracers provide the advantage of deep tissue penetration and low background compared with optical imaging techniques. PET and SPECT produce three-dimensional images and are more sensitive than structural imaging. SPECT is less expensive than PET and uses radiotracers with a longer halflife but has a lower resolution. Additionally, linkage of
SPECT tracers requires modifications that might interfere with binding of the marker to the target.

Use of molecular imaging methods might facilitate early diagnosis, disease monitoring, and guidance of treatment strategy, but studies unequivocally demonstrating their value in daily practice are needed. Molecular imaging could be very useful for the selection of patients in phase II clinical trials that evaluate new drugs in a small patient group. The imaging allows measurement of the expression of a given therapeutic target in each individual patient. The level of this expression may be used to select those patients who are most likely to respond to the new therapy. Such an analysis may limit the number of patients who are required in a phase II proof-of-concept trial and may improve the chances of success, but will depend on factors such as the interindividual variability and the response stratification prediction of the imaging. Imaging is also a powerful tool for animal experimentation; it enables researchers to gather data over a period of time in the same animal. Since the 1990s, molecular imaging has been applied to study arthritis in preclinical imaging of experimental animal models and has evolved from the use of simpler methods, such as autoradiography and planar gamma camera imaging, to more advanced techniques, including fluorescence, PET, and SPECT imaging, that show higher sensitivity and provide more detailed information. The development of the necessary equipment allowing small animal imaging has led to important progress in the field. Fluorescence imaging has greatly advanced as a whole-animal imaging technique and this is due mostly to the development of NIR fluorophores. The background signal in lower wavelengths strongly decreases sensitivity of fluorescence imaging but is significantly less in the NIR range. Nuclear imaging has become more accessible for preclinical research as well; PET and SPECT scanners have been adapted for imaging of small animals.

\section{Emerging techniques and markers to facilitate molecular imaging of arthritis}

\section{Probes for molecular imaging}

Molecular imaging probes should hold some key properties (that is, rapid binding with high affinity and specificity for the target, rapid clearance of unbound molecules, high target-to-background ratio, high stability, low immunogenicity and toxicity, and feasibility with respect to production and cost). Probes can be constructed from small molecules, peptides, proteins, antibodies, the antigen-binding region of antibodies (Fab fragments), nanobodies, and nanoparticles (Figure 2). Antibodies are frequently used for specific targeting as they have several advantages over other probes. Generic processes for production of monoclonal antibodies are 


\begin{tabular}{|l|l|}
\hline Molecular imaging probes: \\
\hline Small molecules & $\begin{array}{l}\text { Low molecular weight substances ( } \leq 900 \text { Da) that are } \\
\text { synthetised by chemical reactions between organic and/or } \\
\text { inorganic compounds, e.g. methylene diphosphonate. }\end{array}$ \\
\hline Peptides & $\begin{array}{l}\text { Natural or synthetic compounds containing two or more amino } \\
\text { acids, e.g. arginine-glycine-aspartic acid (RGD) tripeptide. }\end{array}$ \\
\hline Proteins & $\begin{array}{l}\text { Compound consisting of one or more chains of amino acids, } \\
\text { e.g. annexin. }\end{array}$ \\
\hline Antibodies & $\begin{array}{l}\text { Proteins, immunoglobulins, that recognize and bind with high } \\
\text { affinity to the antigen they were raised against. Antibodies } \\
\text { consist of two heavy chains and two light chains }(\sim 150 \mathrm{kDa}), \\
\text { e.g. anti-TNF- } \alpha \text { antibodies. }\end{array}$ \\
\hline Antibody fragments & $\begin{array}{l}\text { Proteins comprising only one constant and one variable domain } \\
\text { of the heavy and light chains of an antibody }(\sim 50 \mathrm{kDa}), \text { eg. } \\
\text { anti-E-selectin Fab fragments. }\end{array}$ \\
\hline Nanobodies & $\begin{array}{l}\text { The cloned } \mathrm{V}_{\mathrm{HH}} \text { domain of a heavy-chain antibody occuring in } \\
\text { certain animal species }(\sim 15 \text { kDa), e.g. MMR-targeting } \\
\text { nanobodies. }\end{array}$ \\
\hline Nanoparticles & $\begin{array}{l}\text { Particles of } 1 \text { to } 100 \text { nm that possess unique material } \\
\text { characteristics, e.g. chitosan nanoparticles. }\end{array}$ \\
\hline
\end{tabular}

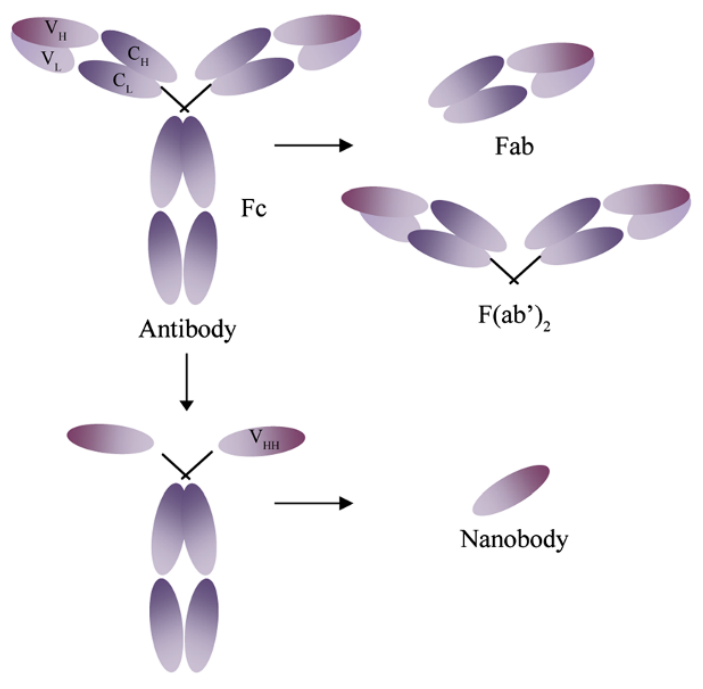

Heavy-chain antibody

Figure 2 Probes can be composed of small molecules, peptides, proteins, antibodies, antibody fragments, nanobodies, and nanoparticles. A schematic overview of a conventional antibody, a heavy-chain antibody, Fab fragments, and a nanobody is given. $C_{H}$, heavy chain constant domain; $C_{L}$ light chain constant domain; Fab, antigen-binding domain; FC, constant domain; MMR, macrophage mannose receptor; TNF-a, tumor necrosis factor-alpha; $V_{H}$, heavy chain variable domain; $V_{H H}$, heavy chain only antibody $V_{L}$, light chain variable domain.

well established, and monoclonal antibodies are highly specific as they recognize a single molecular epitope. On the downside, antibodies may bind non-specifically via their Fc domains. Antibody administration can trigger undesirable anti-immune responses. To increase target specificity and reduce immunogenicity, Fab fragment probes, comprising only one constant and one variable domain of the heavy and light chains, can be used instead of the complete antibody (Figure 2). An emerging technique in molecular imaging is the use of nanobodies (that is, functional variable fragments of single-chain antibodies that are produced by camelids) (Figure 2). The single-variable domain can be cloned relatively easily from lymphocytes of immunized animals. Nanobodies possess full antigen-binding capacity and are very stable [22]. Their small size $(15 \mathrm{kDa})$ enables them to reach epitopes that are shielded for larger antibodies and additionally allows rapid clearance of unbound tracer from the body. Nanobodies can easily be formatted to meet the needs of several applications [23]. For SPECT imaging, their high intrinsic thermostability and carboxy-terminal hexahistidine tail allow straightforward ${ }^{99} \mathrm{~m}$ Tc-labeling using tricarbonyl chemistry $[24,25]$. In addition, nanobodies have been validated as tracers for other imaging modalities (for example, NIR-labeled nanobodies for optical imaging [26] and nanobodycoupled microbubbles for ultrasound [27]). Imaging with labeled nanobodies has proven its value in preclinical models for atherosclerosis and tumors. SPECT imaging with ${ }^{99} \mathrm{~m}$ Tc-labeled nanobodies targeting vascular cell adhesion molecule-1 (VCAM-1) in apolipoprotein E-deficient mice identified aortic arch atherosclerotic lesions [28]. Nanobodies against the macrophage mannose receptor (MMR) (CD206) were successfully used in SPECT imaging to specifically visualize a subpopulation of tumor-infiltrating macrophages in mammary adenocarcinoma and Lewis lung carcinoma models in mice [29].

Development of new molecular imaging probes for introduction into the clinic is challenging. The regulatory pathway for diagnostics shares features with that for new therapeutics, but the potential revenue from commercialization is lower.

\section{The use of molecular imaging in the clinic General tracers}

A frequently used PET tracer is ${ }^{18}$ F-fluoro-2-deoxy-Dglucose $\left({ }^{18} \mathrm{~F}-\mathrm{FDG}\right)$, which is used to image glucose metabolism. Glucose is normally taken up by cells and phosphorylated by hexokinase. ${ }^{18} \mathrm{~F}$-FDG, on the other hand, cannot be metabolized and therefore accumulates in cells [1]. PET with ${ }^{18} \mathrm{~F}$-FDG is used in experimental models as well as in the clinic to study inflammation of joints by detecting its accumulation in activated macrophages, neutrophils, and proliferating fibroblasts $[1,30]$. The technique has been successfully used to image RA-related inflammation and even to predict the response to therapy of patients with RA. A 
correlation was noted between PET activity 2 weeks after initiation of infliximab treatment and the disease activity score 28 after 14 and 22 weeks of treatment [31]. Increased uptake of ${ }^{18}$ F-FDG in the joints is not specific for RA, as this also occurs in infectious and degenerative forms of osteoarthritis [32]. Radiolabeled diphosphonates do not locate primarily to inflammatory sites, but detect alterations in bone metabolism, especially increased pathological osteoblast activity $[33,34]$. SPECT imaging with ${ }^{99 m}$ technetium-methylene diphosphonate $\left({ }^{99 \mathrm{~m}} \mathrm{Tc}-\mathrm{MDP}\right)$ is clinically approved for the assessment of bone damage in RA and is used to monitor patients with active arthritis [33] (Figure 3). This tracer has proven to be useful for arthritis imaging in the past but provides limited insight into the disease process. Furthermore, uptake of ${ }^{99 m}$ Tc-MDP occurs in all joints, making discrimination with mild arthritis difficult and precluding differentiation between active synovitis and inflammation secondary to joint destruction in chronically affected joints. Other general probes (discussed in Table 1 ) have yielded positive results in trials with patients with RA, but many have not been further developed for this application, mostly as a result of the limited information they provide in addition to clinical assessment in comparison with more specific probes. Consequently, additional imaging probes are being evaluated for assessment of synovitis in patients.

\section{Radiolabeled biologicals}

Several biologicals approved for the treatment of RA have been radiolabeled and evaluated for imaging, and this provides a number of advantages. These drugs are already being developed commercially, and their safety has been assessed. Radiolabeled therapeutics might provide an earlier, more specific diagnosis and facilitate monitoring of treatment efficacy. Importantly, confirmation of the presence of the target in the patient before treatment initiation provides the possibility of personalized therapy, which can significantly reduce treatment costs. In this context, anti-CD3 [46-48], anti-CD4 [42-45], anti-CD20 [53,54], and anti-TNF- $\alpha$ (infliximab $[2,50]$ and adalimumab $[51,52])$ have been evaluated for imaging of RA, and most perform relatively well. An exception is IL-1 receptor antagonist (anakinra), which failed to show any specific localization in synovia of RA patients as compared with healthy synovia [49]. As evident from clinical trials, uptake of radiolabeled monoclonal anti-CD3 antibodies (OKT-3), which target all $\mathrm{T}$ cells, was detectable in inflamed joints of patients with RA and levels correlated with inflammation scores from physical examination [46-48]. Anti-CD4 antibodies (MAX.16H5) target a more specific subset of T lymphocytes. These antibodies were also evaluated for visualization of inflammatory foci in patients with RA [42-45]. Early studies on the specificity of the antibody signal yielded conflicting results [73], but this specificity

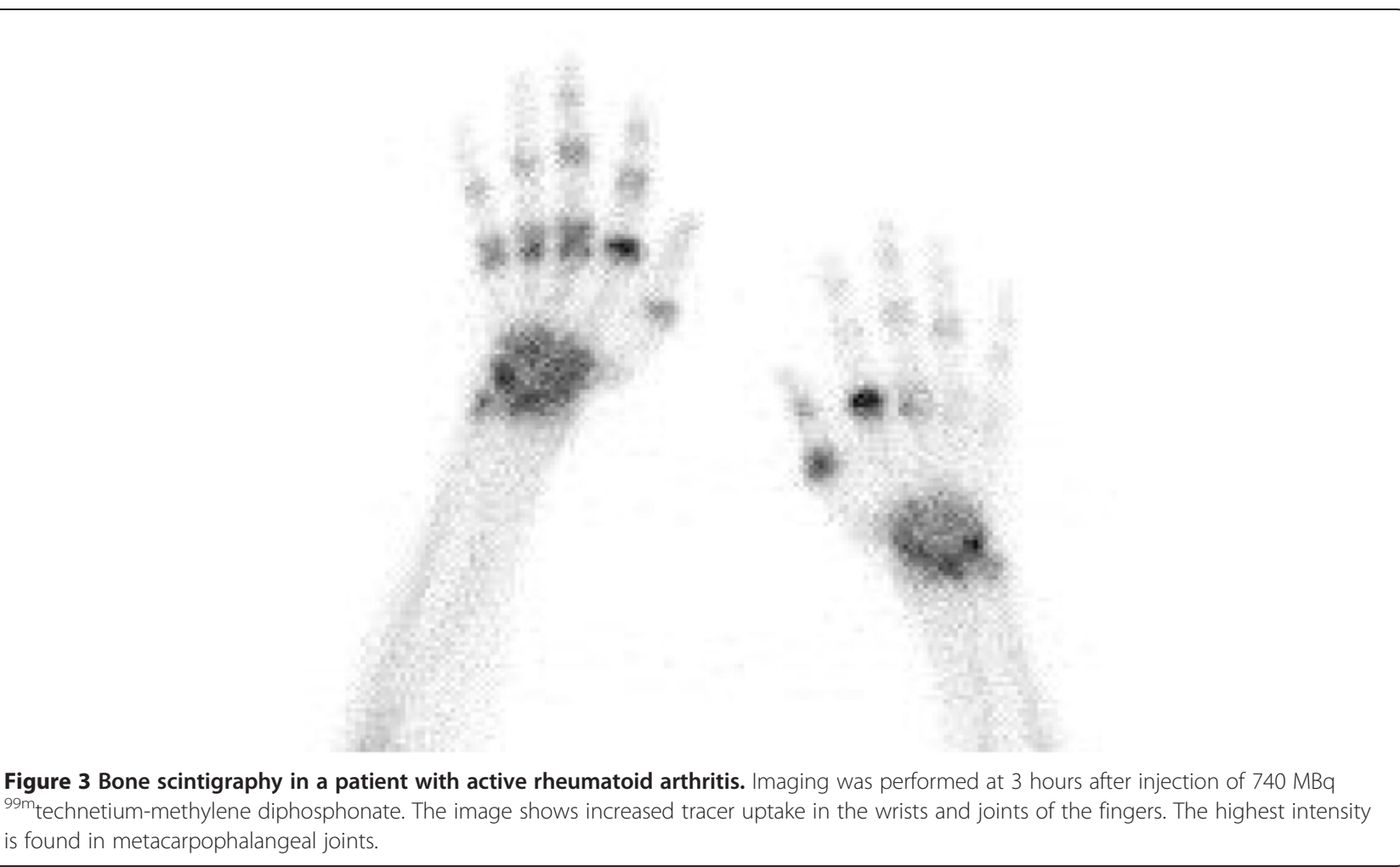




\begin{tabular}{|c|c|c|c|}
\hline Tracer & Target & Developmental phase & Reference \\
\hline \multicolumn{4}{|l|}{ General tracers } \\
\hline${ }^{18}$ F-fluoro-2-deoxy-D-glucose & Glucose metabolism, inflammation & Clinical use for detection of inflammation and cancer & {$[1,35]$} \\
\hline${ }^{99 m}$ Tc-diphosphonates & Alterations in bone metabolism, osteoblastic activity & Clinical use for bone scanning & {$[33,34]$} \\
\hline \multirow[t]{2}{*}{${ }^{11}$ C-choline } & \multirow[t]{2}{*}{ Cell membrane synthesis, inflammation } & Clinical use for detection of prostate cancer & \multirow[t]{2}{*}[36,37]{} \\
\hline & & Trial in 10 patients with inflammatory joint disease & \\
\hline${ }^{67}$ Ga-citrate & $\begin{array}{l}\text { Circulating blood plasma proteins and } \\
\text { leukocytes, inflammation }\end{array}$ & Clinical use for detection of inflammation & [14] \\
\hline${ }^{99 m}$ Tc-polyclonal human immunoglobulin $\mathrm{G}$ & $\begin{array}{l}\text { Increase in vascular permeability, hyperemia, } \\
\text { inflammation }\end{array}$ & Multiple trials in patients with rheumatic disorders & {$[38,39]$} \\
\hline \multirow[t]{2}{*}{${ }^{99 \mathrm{~m}_{\mathrm{Tc}}-{ }^{111} \text { In-labeled leukocytes }}$} & \multirow[t]{2}{*}{ Influx of leukocytes into inflamed tissue } & Clinical use for infectious and inflammatory disorders & \multirow[t]{2}{*}{ [40] } \\
\hline & & Multiple trials in patients with RA & \\
\hline${ }^{99 \mathrm{~m}} \mathrm{Tc}-\mathrm{RP} 128$ & $\begin{array}{l}\text { Leukocytes (binds to receptors on } \\
\text { neutrophils and mononuclear phagocytes) }\end{array}$ & Trial with 10 patients with RA & [41] \\
\hline \multicolumn{4}{|l|}{ Radiolabeled biologicals } \\
\hline${ }^{99 \mathrm{~m}} \mathrm{~T}$ c-anti-CD4 mAb & T cells & $\begin{array}{l}\text { Case study in } 1 \text { patient with RA, trial in } \\
6 \text { patients with RA }\end{array}$ & {$[42-45]$} \\
\hline${ }^{99 m}$ Tc-anti-CD3 mAb & T cells & $\begin{array}{l}\text { Trials in } 7 \text { patients with RA, } 2 \text { psoriatic arthritis } \\
\text { patients, and } \\
38 \text { patients with RA }\end{array}$ & [46-48] \\
\hline${ }^{123}$-IL-1Ra & Inflammation & Trial in 4 patients with active RA & [49] \\
\hline \multirow[t]{2}{*}{${ }^{99 m}$ Tc-anti-TNF-a } & \multirow[t]{2}{*}{ Inflammation } & Multiple trials with patients with RA & \multirow[t]{2}{*}[2,50-52]{} \\
\hline & & Phase 3 study (NCT01590966) & \\
\hline${ }^{99 m_{T}}$ - $-{ }^{124}$-anti-CD20 mAb & B cells & $\begin{array}{l}\text { Trials in } 6 \text { patients with RA and } 20 \text { patients } \\
\text { with chronic inflammatory autoimmune disease }\end{array}$ & {$[53,54]$} \\
\hline \multicolumn{4}{|l|}{ Specific molecular markers } \\
\hline \multirow[t]{2}{*}{${ }^{99 m}$ Tc-acetylated poly-(1,3)-D-galactoside } & \multirow{2}{*}{$\begin{array}{l}\text { Mononuclear phagocyte trafficking } \\
\text { (binds CD14 and CD11b) }\end{array}$} & Trials for tumoral, inflammatory and infectious diseases & \multirow[t]{2}{*}{ [55] } \\
\hline & & Preclinical, rabbit antigen-induced arthritis & \\
\hline \multirow[t]{2}{*}{${ }^{99 \mathrm{~m}} \mathrm{Tc}-\int^{111} \operatorname{In}$-octreotide } & \multirow{2}{*}{$\begin{array}{l}\text { Endothelium activation and macrophage recruitment } \\
\text { (binds to somatostatin receptor) }\end{array}$} & Clinical use for detection of tumors & \multirow[t]{2}{*}{ [56] } \\
\hline & & Trial in 14 patients with RA & \\
\hline${ }^{11} \mathrm{C}-(\mathrm{R})-\mathrm{PK} 11195$ & $\begin{array}{l}\text { Monocytes and macrophages (binds to peripheral } \\
\text { benzodiazepine receptors) }\end{array}$ & $\begin{array}{l}\text { Trials in } 11 \text { patients with RA, } 6 \text { patients with RA, and } \\
29 \text { patients with arthralgia }\end{array}$ & {$[57,58]$} \\
\hline
\end{tabular}

\section{Radiolabeled biologicals}

${ }^{99 m} \mathrm{Tc}$-anti-CD4 mAb

Trials in 11 patients with RA, 6 patients with RA, and

29 patients with arthralgia 
Table 1 Available imaging agents for rheumatoid or experimental arthritis (Continued)

\begin{tabular}{|c|c|c|c|}
\hline${ }^{111}$ In-E-selectin-binding peptide & Activated vascular endothelium & Preclinical, rat adjuvant arthritis & [59] \\
\hline${ }^{99 \mathrm{~m}} \mathrm{Tc}$-anti-E-selectin $\mathrm{Fab} /\left(\mathrm{Fab}^{\prime}\right)_{2}$ fragment & Activated vascular endothelium & Trial in 26 patients with RA & {$[60]$} \\
\hline NIR-anti-E-selectin Ab & Activated vascular endothelium & Preclinical, CIA, and TNF-a-induced paw edema & [61] \\
\hline \multirow[t]{2}{*}{${ }^{99 \mathrm{~m}} \mathrm{Tc}$-annexin $\mathrm{V}$} & \multirow[t]{2}{*}{ Apoptosis (binds to phosphatidylserine) } & Multiple trials in cancer patients & \multirow[t]{2}{*}[62]{} \\
\hline & & Preclinical, CIA & \\
\hline Cy5.5-anti-F4/80 & Macrophages & Preclinical, AIA & [63] \\
\hline${ }^{99 m}$ Tc-anti-IL-6R & Inflammation & Preclinical, murine arthritis model & [64] \\
\hline${ }^{99 m}$ Tc-folic acid (EC20) & Activated macrophages, folate receptor & $\begin{array}{l}\text { Phase } 2 \text { study in patients with autoimmune disease } \\
\text { (NCT00588393) }\end{array}$ & {$[65-67]$} \\
\hline NIR2-folate & Activated macrophages, folate receptor & Mouse arthritis models & {$[68]$} \\
\hline${ }^{18}$ F-PEG-folate & Activated macrophages, folate receptor & $\begin{array}{l}\text { Preclinical, methylated bovine serum } \\
\text { albumin-induced arthritis }\end{array}$ & [69] \\
\hline \multirow{2}{*}{$\begin{array}{l}{ }^{64} \mathrm{Cu}-/{ }^{18} \mathrm{~F} \text {-galacto-arginine- } \\
\text { glycine-aspartic acid }\end{array}$} & \multirow[t]{2}{*}{ Activated macrophages, osteoclasts, endothelial cells } & Clinical use, tumor angiogenesis & \multirow[t]{2}{*}[70]{} \\
\hline & & $\begin{array}{l}\text { Preclinical, osteopetrosis, and osteoporosis } \\
\text { mouse models }\end{array}$ & \\
\hline $\begin{array}{l}\text { NIR-matrix metalloproteinase- } \\
\text { specific probe }\end{array}$ & Sites of matrix degradation and inflammation & Preclinical, $\mathrm{CIA}$, rat OA & [71] \\
\hline $\begin{array}{l}{ }^{99 m} \text { Tc-anti-macrophage } \\
\text { mannose receptor }\end{array}$ & Subset of macrophages & Preclinical, CIA & [72] \\
\hline
\end{tabular}


was later confirmed in a study using Fab fragments. A higher accumulation of anti-CD4 Fab' fragments compared with control Fab' fragments was clearly shown in adjuvantinduced arthritis [74]. Rituximab, a chimeric monoclonal anti-CD20 antibody, is licensed for treatment of RA and has demonstrated good efficacy in a subset of patients [75]. ${ }^{99 m}$ Tc-rituximab was shown to localize in inflamed joints of patients with RA [53,54]. Here, an interesting intraarticular and inter-individual variability was exposed, providing an explanation for the failure of anti-CD20 therapy in certain patients [54]. Finally, with respect to anti-TNF- $\alpha$, imaging of patients with active RA by using ${ }^{99 \mathrm{~m}} \mathrm{Tc}$-antiTNF- $\alpha$ showed a high correlation with inflammation detected by MRI and proved to be more sensitive than clinical examination [52]. In addition, Conti and colleagues [2] reported that imaging with anti-TNF- $\alpha$ in patients with active arthritis just before treatment with infliximab could predict the efficacy of the anti-TNF- $\alpha$ therapy.

As evident from Table 1, these radiopharmaceuticals have been evaluated in trials dating back several years; for some of them, no real implementation in imaging has been reported in recent years. Further development of radiolabeled drugs for imaging purposes is subjected to important limitations: (a) the safety issues of murine and chimeric monoclonal antibodies; problems with immunogenicity are now being handled by humanization of the antibodies. (b) The safety profile of the pharmaceutical. Administration of antiCD3 antibodies, for example, may cause serious adverse effects in some patients, such as the cytokine release syndrome. (c) The inefficacy of certain drugs in patients with RA. As mentioned, anti-CD4 antibody was demonstrated to have potential for location of inflammatory regions, but the lack of therapeutic results in RA has halted further development for imaging. (d) The high costs associated with development and production of these therapies.

In our opinion, radiolabeled anti-CD20 and anti-TNF$\alpha$ antibodies show the most potential for clinical use. Their effectiveness as treatment for RA has been established, and the first results on identification of patients who will respond to therapy look promising. Further implementation studies demonstrating their value in selecting patients for specific therapies are needed. Currently, conflicting results are found in the literature - coming mostly from registries - about switching to another mode of action or to another TNF blocker in patients failing their first anti-TNF treatment [76,77]. In the future, the use of radiolabeled antibodies in appropriate randomized studies could help to produce more solid data that might give guidance to clinicians.

\section{Specific tracers for imaging of arthritis in preclinical models}

Molecular imaging in animal models is necessary for the development of new tracers but can also be used as an additional objective parameter to assess arthritis in an experimental context, thereby providing detailed information on the disease process. Tracers have evolved to target molecules more specifically than ${ }^{18}$ F-FDG or ${ }^{99 m} \mathrm{Tc}-$ MDP, which visualize general processes (glucose metabolism and bone turnover), and we can see an evolution in the use of more sophisticated techniques for preclinical research. An example of the technical evolution can be seen in the development of tracers that target the folate receptor, a $38-\mathrm{kDa}$ glycosyl-phosphatidylinositol-anchored protein that binds folic acid [65]. The folate receptor is expressed at very low levels in most tissues in homeostatic conditions, except for the kidneys and placenta. Under these circumstances, folic acid is taken up by carriers [78]. Expression of the folate receptor in pathogenic conditions seems to be restricted to several cancer cells and activated macrophages. Interestingly, high-level expression of this receptor was found in activated synovial macrophages from patients with RA [79], a feature that has been exploited in imaging. In 2002, Turk and colleagues [66] published a study in which the folate receptor was targeted in rats with adjuvantinduced arthritis by using ${ }^{99 \mathrm{~m}}$ Tc-labeled folic acid. Gamma scintigraphy was applied to produce images of the inflamed paws, and uptake could be detected in arthritic joints [66]. However, the resolution of this technique is very low. Chen and colleagues [68] developed a fluorescence-labeled folate probe (NIR2-folate) that allowed improved resolution in two mouse models of arthritis and the possibility of detecting arthritis at an early time point. So far, however, fluorescent imaging is being hindered by limited tissue penetration and is not yet optimized for use in patients with RA. Recently, an improved PET tracer $\left({ }^{18} \mathrm{~F}\right.$-polyethylene glycol-folate) targeting the folate receptor was shown to hold promise for imaging RA in patients, as it was successfully used in an antigen-induced arthritis model [69]. A folate receptor-targeting agent, ${ }^{99 \mathrm{~m}} \mathrm{Tc}-\mathrm{EC} 20$ (FolateScan), has been produced and evaluated in the clinic for the assessment of inflammation in joints of patients with RA or other diseases $[67,80]$. In a study including 40 RA patients with active and inactive disease, joint involvement was assessed by screening with FolateScan. The number of actively involved joints identified by FolateScan correlated with erythrocyte sedimentation rates and C-reactive protein levels. Larger numbers of actively involved joints were detected with FolateScan than were identified by clinical examination. It was concluded that imaging with FolateScan may be a more sensitive method than physical examination for assessing disease activity [67]. Upregulation of the folate receptor in activated macrophages is also being exploited for targeting of folate-linked drugs to these macrophages in RA [81,82]. Imaging with FolateScan might help to predict the success rate of this technique.

F4/80, a member of the epidermal growth factor transmembrane 7 family, is expressed on a variety of 
macrophage subsets. Macrophages that accumulate in inflamed joints express F4/80. In a mouse model, imaging with NIR-labeled antibodies targeting F4/80 visualized macrophage accumulation in arthritic joints, with some background in healthy paws [63]. The MMR is a $175-\mathrm{kDa}$ C-type lectin expressed predominantly by mature macrophages and certain endothelial and dendritic cells. It is detected in spleen, liver, and lymph nodes and its primary functions are endocytic clearance of certain glycoproteins and phagocytosis of unopsonized microorganisms [83]. Our research group recently reported the successful use of radiolabeled nanobodies targeting MMR for in vivo SPECT/CT imaging of mice with CIA (Figure 4) [72]. We were able to visualize $\mathrm{CD} 11 \mathrm{~b}^{+} \mathrm{F} 4 / 80^{+}$ macrophages in the inflamed joints of these mice, thereby providing a means to quantify the inflammation in an objective manner and obtaining more knowledge on the pathogenesis of arthritis, since MMR had previously not been shown to be expressed in the rheumatic synovium [72].

Vascular endothelium, activated in inflammatory processes, transiently expresses the surface glycoprotein Eselectin in response to cytokines such as IL-1 $\beta$ and TNF- $\alpha$. Selectins facilitate tethering and rolling of leukocytes on endothelium. These mechanisms commence early in the pathogenesis of arthritis. Fluorescently labeled anti-E-selectin antibodies were successfully used for imaging in a mouse model for RA, enabling detection of subclinical manifestations, monitoring effects of therapy, and quantification of disease [61]. In patients with RA, ${ }^{99 \mathrm{~m}} \mathrm{Tc}$-anti-E-selectin-Fab appeared to be suitable for scintigraphic imaging of synovitis and showed a higher specificity than ${ }^{99 \mathrm{~m}} \mathrm{Tc}$ - hydroxymethylene diphosphonate bone imaging [60].
Intercellular adhesion molecule-1 (ICAM-1) is another potential target for imaging of arthritis as it was demonstrated to be expressed on synovial endothelial cells and mice deficient in ICAM-1 showed a reduction in arthritis incidence and severity [84]. In CIA, antibodies targeting ICAM-1 were conjugated to gadolinium diethylenetriamine pentaacetic acid and were able to detect early inflammatory symptoms before the onset of the chronic destructive phase [85].

In arthritic joints, increased apoptotic cells are detected in the synovial membrane [86]. These cells can be imaged by the use of radiolabeled annexin $\mathrm{V}$ that binds to phosphatidylserine, which is associated with the inner leaflet of the plasma membrane. It was found that ${ }^{99} \mathrm{~m} \mathrm{Tc}$-annexin could visualize arthritic joints before the onset of bone destruction [62].

Inflammatory cytokines, such as IL- $1 \beta$ and TNF- $\alpha$, stimulate the production of MMPs that degrade the extracellular matrix. Levels of MMPs increase in the serum and the synovial fluid of patients with RA. MMP$1,-2,-3,-9$, and -13 appear to be most important in RA. Recently, Ryu and colleagues [71] demonstrated the use of an MMP-3-specific polymeric probe for visualization of arthritis by NIR fluorescence imaging. The probe was developed by the conjugation of a NIR dye, an MMP substrate peptide, and a quencher to chitosan nanoparticles. Imaging with this probe allowed early diagnosis of arthritis in mice with CIA. More specifically, at 2 weeks after immunization, before any signs of structural or anatomical changes, a signal from the MMP-3 probe could be detected [71].

Development of these molecular markers is still in its infancy; many have only recently been evaluated for imaging of arthritis in preclinical models. Some show potential for
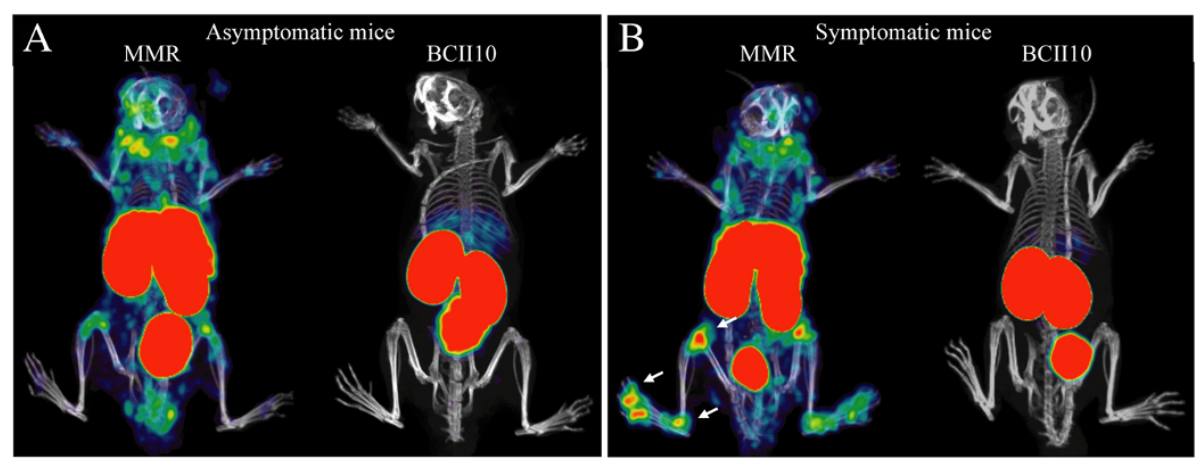

Figure 4 In vivo imaging with macrophage mannose receptor (MMR)-specific nanobodies visualizes MMR expression in joints of mice with collagen-induced arthritis. Single-photon emission computed tomography and micro-computed tomography imaging was performed at 3 hours after injection of ${ }^{99 m}$ technetium-labeled MMR-targeting nanobodies in mice without clinical symptoms of arthritis (A) (asymptomatic mice) or mice with arthritic joints (B) (symptomatic mice). Nanobodies against the $\beta$-lactamase BCIl enzyme of Bacillus cereus (BCIl10) were used as a non-targeting control. MMR staining is apparent in knees, ankles, and metatarsal joints of symptomatic mice (arrows) in addition to the signal in lymph nodes, liver, and spleen that is also detectable in asymptomatic mice. This image was originally published in the Journal of Nuclear Medicine [72]. $\odot$ by the Society of Nuclear Medicine and Molecular Imaging, Inc. 
further development, such as MMP-specific probes, which are being commercialized and are entering research labs. Others are less promising for the future and this is due mostly to lower specificity. The targeted cell type might not be exclusively expressed in the inflamed joint or the probe might bind to irrelevant targets, resulting in nonspecific signals and low target-to-background ratios.

\section{Potential new targets to be considered for in vivo imaging of arthritis}

Molecules in the following section were chosen for discussion because they have been shown, or suggested, to be involved in the pathogenesis of arthritis through functional preclinical studies and expression studies in animal models or patients.

\section{RANK and RANKL}

RANKL is a type I-membrane protein of the TNF receptor superfamily, expressed on osteoblasts and $\mathrm{T}$ cells. RANKL knockout mice exhibit severe osteopetrosis because of a complete absence of osteoclasts. Furthermore, the importance of RANK-RANKL signaling for bone destruction in arthritis has been demonstrated in several studies $[87,88]$. Inhibition of RANKL by denosumab, a human monoclonal antibody, has been effective for the treatment of RA-associated bone loss [89] and bone metastasis in cancer [90]. The receptor for RANKL, RANK, can be detected on pre-osteoclasts in the blood as well as on mature osteoclasts [91]. Importantly, RANK has already proven to be a potential marker for the detection of bone metastasis [92-94]. RANK and RANKL can thus be considered valuable molecular targets for the treatment of bone loss and have great value as markers for RA-associated bone pathology.

\section{Chemokine receptors}

Chemokines and their receptors are involved in the recruitment of leukocytes to the site of inflammation; they are key molecules in the pathogenesis of RA and present possible targets for imaging. CCR1 and CCR5 are the ones most implicated in RA. CCR1 is abundantly expressed by macrophages in the inflamed synovium and peripheral blood monocytes of patients with RA, suggesting an important role in recruitment of leukocytes from the circulation. A trial involving 160 patients with RA showed evidence of a beneficial effect of treatment with the small-molecule CCR1 antagonist CCX354-C [95]. CCR5 is highly expressed in the rheumatoid synovium, particularly by $\mathrm{T}$ helper (Th) 1 lymphocytes [96]. Antagonists of CCR5 have proven to be capable of inhibiting the development of collagenand adjuvant-induced arthritis $[97,98]$.

\section{Surface molecules involved in cell adhesion and cell signaling}

VCAM-1 is thought to be responsible for recruitment and retention of leukocytes in the inflamed synovium. It is found on fibroblast-like synoviocytes in the synovial lining layer and is upregulated upon stimulation with various cytokines [99]. As mentioned, nanobodies targeting VCAM-1 have proven their worth in imaging of atherosclerotic lesions. The expression of VCAM-1 in arthritis suggests that these nanobodies might also be useful in imaging of arthritic joints.

Integrins, a large family of heterodimeric transmembrane glycoproteins, mediate cell-cell and cell-matrix interactions. Their expression is upregulated in the proinflammatory environment of the rheumatoid synovium and leads to production of matrix-degrading enzymes and cytokines [100]. Vitaxin, a humanized monoclonal antibody that blocks the interactions of $\alpha_{v} \beta_{3}$ with its ligands, was tested as treatment for RA in clinical trials [101]. Mature and active osteoclasts express $\alpha_{v} \beta_{3}$; consequently, inhibition or deficiency of the $\beta_{3}$ integrin was shown to cause impaired differentiation and function of osteoclasts [102]. Imaging studies were performed with the tripeptide Arg-Gly-Asp (RGD), which binds with high affinity to $\alpha_{\mathrm{v}} \beta_{3}$. PET imaging with ${ }^{64} \mathrm{Cu}$-labeled RGD allowed detection of changes in osteoclast numbers in mouse models for osteopetrosis or osteoporosis [70], suggesting that ${ }^{64} \mathrm{Cu}$-RGD may be suitable for imaging of osteoclast changes in RA.

Another cell surface molecule implicated in the pathogenesis of RA is the purinoreceptor P2X7, which was shown to be expressed by synoviocytes from RA joints. P2X7 is expressed by various cells, including osteoblasts and osteoclasts, and has been implicated in the formation of multinuclear cells. Triggering of this receptor results in enhanced IL-6 secretion and its absence was shown to result in a loss of ATP-dependent leukocyte function, including IL-1 $\beta$ production and L-selectin shedding [103]. In animal models of arthritis, deficiency of the P2X7 receptor is associated with lower incidence and severity of arthritis [104].

Suppression of tumorigenicity 2 (ST2) is a member of the Toll-like/IL-1 receptor superfamily that participates in inflammatory processes, such as production of Th2 cytokines. The ST2/IL-33 pathway has been implicated in RA pathogenesis, and treatment of CIA with ST2-Fc fusion protein ameliorated the disease and downregulated production of IL-6, IL-12, and TNF- $\alpha$ [105].

Dendritic cell-specific transmembrane protein (DCSTAMP) and osteoclast-stimulatory transmembrane protein (OC-STAMP) are highly expressed by osteoclasts and essential for the fusion of macrophages to multinuclear cells and bone degradation [106]. DC-STAMP was suggested to be a marker for circulating osteoclast 
precursors in inflammatory arthritis as it was found to be increased on peripheral blood mononuclear cells of patients with psoriatic arthritis [107]. DC-STAMP and OC-STAMP could be valuable for therapy development and imaging of osteoclasts in arthritis.

\section{Challenges for development of new molecular probes}

High selectivity of molecular imaging probes is mandatory and represents the most important aspect to consider when developing new candidates for imaging. A second challenge to consider is resolution; theoretically, molecular imaging could also help in showing specific localizations of inflammation, distinguishing enthesitis from arthritis in spondyloarthritis versus RA, but this would require techniques with better resolution. To qualify the cost-effectiveness of a new marker, the molecular imaging method should have an impact on patient management. As stated above, molecular imaging methods might be of help in designing and evaluating proof-of-concept phase I and II trials assessing specific targets. The use of these tools, however, will become established only if they facilitate daily treatment practice in making an appropriate choice for the best treatment option or are able to guide the physician in tapering expensive treatment if a specific state of prolonged remission has been reached. Ultimately, as stated in a recent editorial by Smolen and Aletaha [108], better markers will be needed to make a transition toward real personalized medicine.

\section{Conclusions}

The field of molecular imaging has grown substantially in the past two decades; tools and techniques have evolved, and new molecular markers are being identified. Molecular imaging will be of help in a preclinical context by offering a reliable and subjective manner to assess the disease severity and by providing more detailed knowledge of the disease process. Some of the markers will enter the clinic to facilitate diagnosis, monitoring of disease progression, and determination of treatment strategy in a subset of patients. Finally, an important role for molecular imaging may be situated in the assessment of efficacy of new drugs and in the design and evaluation of clinical trials.

\footnotetext{
Abbreviations

${ }^{18}$ F-FDG: ${ }^{18}$ fluoro-2-deoxy-D-glucose; ${ }^{99 m}$ Tc-MDP: ${ }^{99 m}$ technetium-methylene diphosphonate; CIA: Collagen-induced arthritis; CT: Computed tomography; DC-STAMP: Dendritic cell-specific transmembrane protein; ICAM-

1: Intercellular adhesion molecule-1; IL: Interleukin; MMP: Matrix metalloproteinase; MMR: Macrophage mannose receptor; MRI: Magnetic resonance imaging; NIR: Near-infrared; OC-STAMP: Osteoclast-stimulatory transmembrane protein; PET: Positron emission tomography; RA: Rheumatoid arthritis; RANK: Receptor activator of nuclear factor-kappa-B; RANKL: Receptor activator of nuclear factor-kappa-B ligand; RGD: Arg-Gly-Asp; SPECT: Singlephoton emission computed tomography; ST2: Suppression of tumorigenicity
}

2; Tc: Technetium; Th: T helper; TNF-a: Tumor necrosis factor-alpha; VCAM1: Vascular cell adhesion molecule-1.

\section{Competing interests}

The authors declare that they have no competing interests.

\section{Acknowledgments}

We are grateful to Prof. Alfons Billiau for critical revision of the manuscript. Our work was supported by grants from the Regional Government of Flanders (GOA program), the Belgian Federal Government (Interuniversitary Attraction Poles program), and the Government Agency for Innovation by Science and Technology (IWT, Strategisch Basisch Onderzoek project coordinated by Patrick De Baetselier, Laboratory of Cellular and Molecular Immunology, VIB Laboratory of Myeloid Cell Immunology, Brussels, Belgium).

\section{Author details}

'KU Leuven, Laboratory of Immunobiology, Rega Institute, Minderbroedersstraat 10, 3000 Leuven, Belgium. ${ }^{2}$ Department of Development and Regeneration; Rheumatology, KU Leuven, Skeletal Biology and Engineering Research Center, University Hospital Leuven, Herestraat 49, 3000 Leuven, Belgium. 'Department of Nuclear Medicine, UZ Brussel, Laarbeeklaan 101, 1090 Jette, Brussels, Belgium. ${ }^{4}$ In Vivo Cellular and Molecular Imaging Center, Vrije Universiteit Brussel, Laarbeeklaan 103, 1090 Jette, Brussels, Belgium.

Received: 16 October 2013 Accepted: 8 April 2014

Published: 15 Apr 2014

\section{References}

1. Mountz JM, Alavi A, Mountz JD: Emerging optical and nuclear medicine imaging methods in rheumatoid arthritis. Nat Rev Rheumatol 2012, 8:719-728.

2. Conti F, Malviya G, Ceccarelli F, Priori R, lagnocco A, Valesini G, Signore A: Role of scintigraphy with mTc-infliximab in predicting the response of intraarticular infliximab treatment in patients with refractory monoarthritis. Eur J Nucl Med Mol Imaging 2012, 39:1339-1347.

3. Firestein GS: Evolving concepts of rheumatoid arthritis. Nature 2003, 423:356-361.

4. Mclnnes IB, Schett G: The pathogenesis of rheumatoid arthritis. N Engl J Med 2011, 365:2205-2219.

5. Cascao R, Rosario HS, Souto-Carneiro MM, Fonseca JE: Neutrophils in rheumatoid arthritis: more than simple final effectors. Autoimmun Rev 2010, 9:531-535.

6. Tak PP, Smeets TJ, Daha MR, Kluin PM, Meijers KA, Brand R, Meinders AE, Breedveld FC: Analysis of the synovial cell infiltrate in early rheumatoid synovial tissue in relation to local disease activity. Arthritis Rheum 1997, 40:217-225.

7. Toh ML, Miossec P: The role of T cells in rheumatoid arthritis: new subsets and new targets. Curr Opin Rheumatol 2007, 19:284-288.

8. Silverman GJ, Carson DA: Roles of B cells in rheumatoid arthritis. Arthritis Res Ther 2003, 5:S1-S6.

9. Svensson L, Jirholt J, Holmdahl R, Jansson L: B cell-deficient mice do not develop type II collagen-induced arthritis (CIA). Clin Exp Immunol 1998, 111:521-526.

10. Scher JU: B-cell therapies for rheumatoid arthritis. Bull NYU Hosp Jt Dis 2012, 70:200-203.

11. Niedermeier M, Pap T, Korb A: Therapeutic opportunities in fibroblasts in inflammatory arthritis. Best Pract Res Clin Rheumatol 2010, 24:527-540.

12. Redlich K, Smolen JS: Inflammatory bone loss: pathogenesis and therapeutic intervention. Nat Rev Drug Discov 2012, 11:234-250.

13. Avouac J, Uzan G, Kahan A, Boileau C, Allanore Y: Endothelial progenitor cells and rheumatic disorders. Joint Bone Spine 2008, 75:131-137.

14. Zeman MN, Scott PJ: Current imaging strategies in rheumatoid arthritis. Am J Nucl Med Mol Imaging 2012, 2:174-220.

15. Szkudlarek M, Narvestad E, Klarlund M, Court-Payen M, Thomsen HS, Ostergaard M: Ultrasonography of the metatarsophalangeal joints in rheumatoid arthritis: comparison with magnetic resonance imaging, conventional radiography, and clinical examination. Arthritis Rheum 2004, 50:2103-2112.

16. Wakefield RJ, Balint PV, Szkudlarek M, Filippucci E, Backhaus M, D'Agostino MA, Sanchez EN, lagnocco A, Schmidt WA, Bruyn GA, Kane D, O'Connor PJ, Manger B, Joshua F, Koski J, Grassi W, Lassere MN, Swen N, Kainberger F, 
Klauser A, Ostergaard M, Brown AK, Machold KP, Conaghan PG, OMERACT 7 Special Interest Group: Musculoskeletal ultrasound including definitions for ultrasonographic pathology. J Rheumatol 2005, 32:2485-2487.

17. Klarlund M, Ostergaard M, Jensen KE, Madsen JL, Skjodt H, Lorenzen I: Magnetic resonance imaging, radiography, and scintigraphy of the finger joints: one year follow up of patients with early arthritis, The TIRA Group. Ann Rheum Dis 2000, 59:521-528.

18. McQueen FM, Stewart N, Crabbe J, Robinson E, Yeoman S, Tan PL, McLean $L$ : Magnetic resonance imaging of the wrist in early rheumatoid arthritis reveals a high prevalence of erosions at four months after symptom onset. Ann Rheum Dis 1998, 57:350-356.

19. Savnik A, Malmskov H, Thomsen HS, Graff LB, Nielsen H, DanneskioldSamsoe B, Boesen J, Bliddal H: MRI of the wrist and finger joints in inflammatory joint diseases at 1-year interval: MRI features to predict bone erosions. Eur Radiol 2002, 12:1203-1210.

20. McQueen FM, Stewart N, Crabbe J, Robinson E, Yeoman S, Tan PL, McLean $L$ : Magnetic resonance imaging of the wrist in early rheumatoid arthritis reveals progression of erosions despite clinical improvement. Ann Rheum Dis 1999, 58:156-163.

21. McQueen FM, Benton N, Crabbe J, Robinson E, Yeoman S, McLean L, Stewart N: What is the fate of erosions in early rheumatoid arthritis? Tracking individual lesions using $x$ rays and magnetic resonance imaging over the first two years of disease. Ann Rheum Dis 2001, 60:859-868

22. Hamers-Casterman C, Atarhouch T, Muyldermans S, Robinson G, Hamers C, Songa EB, Bendahman N, Hamers R: Naturally occurring antibodies devoid of light chains. Nature 1993, 363:446-448.

23. Wesolowski J, Alzogaray V, Reyelt J, Unger M, Juarez K, Urrutia M, Cauerhff A, Danquah W, Rissiek B, Scheuplein F, Schwarz N, Adriouch S, Boyer O, Seman M, Licea A, Serreze DV, Goldbaum FA, Haag F, Koch-Nolte F: Single domain antibodies: promising experimental and therapeutic tools in infection and immunity. Med Microbiol Immunol 2009, 198:157-174.

24. De Groeve K, Deschacht N, De Koninck C, Caveliers V, Lahoutte T, Devoogdt N, Muyldermans S, De Baetselier P, Raes G: Nanobodies as tools for in vivo imaging of specific immune cell types. J Nucl Med 2010, 51:782-789.

25. Schoonooghe S, Laoui D, Van Ginderachter JA, Devoogdt N, Lahoutte T, De Baetselier P, Raes G: Novel applications of nanobodies for in vivo bioimaging of inflamed tissues in inflammatory diseases and cancer. Immunobiology 2012, 217:1266-1272.

26. Oliveira S, van Dongen GA, Stigter-van Walsum M, Roovers RC, Stam JC, Mali W, Van Diest PJ, Henegouwen PM VBe: Rapid visualization of human tumor xenografts through optical imaging with a near-infrared fluorescent anti-epidermal growth factor receptor nanobody. Mol Imaging 2012, 11:33-46.

27. Hernot S, Unnikrishnan S, Du Z, Shevchenko T, Cosyns B, Broisat A, Toczek J, Caveliers V, Muyldermans S, Lahoutte T, Klibanov AL, Devoogdt N: Nanobody-coupled microbubbles as novel molecular tracer. J Control Release 2012, 158:346-353.

28. Broisat A, Hernot S, Toczek J, De Vos J, Riou LM, Martin S, Ahmadi M, Thielens N, Wernery U, Caveliers V, Muyldermans S, Lahoutte T, Fagret D, Ghezzi C, Devoogdt N: Nanobodies targeting mouse/human VCAM1 for the nuclear imaging of atherosclerotic lesions. Circ Res 2012, 110:927-937.

29. Movahedi K, Schoonooghe S, Laoui D, Houbracken I, Waelput W, Breckpot K, Bouwens L, Lahoutte T, De Baetselier P, Raes G, Devoogdt N, Van Ginderachter JA: Nanobody-based targeting of the macrophage mannose receptor for effective in vivo imaging of tumor-associated macrophages. Cancer Res 2012, 72:4165-4177.

30. Irmler IM, Opfermann T, Gebhardt P, Gajda M, Brauer R, Saluz HP, Kamradt T: In vivo molecular imaging of experimental joint inflammation by combined (18)F-FDG positron emission tomography and computed tomography. Arthritis Res Ther 2010, 12:R203.

31. Elzinga EH, van der Laken CJ, Comans EF, Boellaard R, Hoekstra OS, Dijkmans BA, Lammertsma AA, Voskuyl AE: 18 F-FDG PET as a tool to predict the clinical outcome of infliximab treatment of rheumatoid arthritis: an explorative study. J Nucl Med 2011, 52:77-80.

32. Elzinga EH, van der Laken CJ, Comans EF, Lammertsma AA, Dijkmans BA, Voskuyl AE: 2-Deoxy-2-[F-18]fluoro-D-glucose joint uptake on positron emission tomography images: rheumatoid arthritis versus osteoarthritis. Mol Imaging Biol 2007, 9:357-360.
33. Sahin M, Bernay I, Basoglu T, Canturk F: Comparison of Tc-99 m MDP, Tc$99 \mathrm{~m} \mathrm{HSA}$ and Tc-99 m HIG uptake in rheumatoid arthritis and its variants. Ann Nucl Med 1999, 13:389-395.

34. Wong KK, Piert M: Dynamic bone imaging with 99mTc-labeled diphosphonates and 18 F-NaF: mechanisms and applications. J Nucl Med 2013, 54:590-599.

35. Goerres GW, Forster A, Uebelhart D, Seifert B, Treyer V, Michel B, von Schulthess GK, Kaim AH: F-18 FDG whole-body PET for the assessment of disease activity in patients with rheumatoid arthritis. Clin Nucl Med 2006, 31:386-390.

36. Roivainen A, Parkkola R, Yli-Kerttula T, Lehikoinen P, Viljanen T, Mottonen $T$, Nuutila $P$, Minn $H$ : Use of positron emission tomography with methyl-11C-choline and 2-18 F-fluoro-2-deoxy-D-glucose in comparison with magnetic resonance imaging for the assessment of inflammatory proliferation of synovium. Arthritis Rheum 2003, 48:3077-3084.

37. Roivainen A, Yli-Kerttula T: Whole-body distribution of C-choline and uptake in knee synovitis. Eur J Nucl Med Mol Imaging 2006, 33:1372-1373

38. de Bois MH, Westedt ML, Arndt JW, Wiarda KS, van der Velde EA, Pauwels EK, Breedveld FC: Value of $99 \mathrm{mTc}-\mathrm{lgG}$ scintigraphy in the prediction of joint destruction in patients with rheumatoid arthritis of recent onset. Rheumatol Int 1995, 15:155-158.

39. Pons F, Sanmarti R, Herranz R, Collado A, Piera C, Vidal-Sicart S, MunozGomez J, Setoain J: Scintigraphic evaluation of the severity of inflammation of the joints with $99 \mathrm{TCm}$-HIG in rheumatoid arthritis. Nucl Med Commun 1996, 17:523-528.

40. Bennink RJ, Thurlings RM, van Hemert FJ, Voermans C, Dohmen SE, van EckSmit BL, Tak PP, Busemann-Sokole E: Biodistribution and radiation dosimetry of $99 \mathrm{mTc}$-HMPAO-labeled monocytes in patients with rheumatoid arthritis. J Nucl Med 2008, 49:1380-1385.

41. Caveliers V, Goodbody AE, Tran LL, Peers SH, Thornback JR, Bossuyt A: Evaluation of $99 \mathrm{mTc}-\mathrm{RP} 128$ as a potential inflammation imaging agent: human dosimetry and first clinical results. J Nucl Med 2001, 42:154-161.

42. Kinne RW, Becker W, Schwab J, Schwarz A, Kalden JR, Emmrich F, Burmester GR, Wolf F: Imaging rheumatoid arthritis joints with technetium-99 m I abelled specific anti-CD4- and non-specific monoclonal antibodies. Eur J Nucl Med 1994, 21:176-180.

43. Kinne RW, Emmrich F, Freesmeyer M: Clinical impact of radiolabeled antiCD4 antibodies in the diagnosis of rheumatoid arthritis. Q J Nucl Med Mol Imaging 2010, 54:629-638.

44. Becker W, Emmrich F, Horneff G, Burmester G, Seiler F, Schwarz A, Kalden J, Wolf F: Imaging rheumatoid arthritis specifically with technetium $99 \mathrm{~m}$ CD4-specific (T-helper lymphocytes) antibodies. Eur J Nucl Med 1990 17:156-159.

45. Kinne RW, Becker W, Schwab J, Horneff G, Schwarz A, Kalden JR, Emmrich F, Burmester GR, Wolf F: Comparison of 99Tcm-labelled specific murine antiCD4 monoclonal antibodies and nonspecific human immunoglobulin for imaging inflamed joints in rheumatoid arthritis. Nucl Med Commun 1993, 14:667-675.

46. Marcus C, Thakur ML, Huynh TV, Louie JS, Leibling M, Minami C, Diggles L: Imaging rheumatic joint diseases with anti-T lymphocyte antibody OKT3. Nucl Med Commun 1994, 15:824-830.

47. Martins FP, Gutfilen B, de Souza SA, de Azevedo MN, Cardoso LR, Fraga R, da Fonseca LM: Monitoring rheumatoid arthritis synovitis with 99mTcanti-CD3. Br J Radiol 2008, 81:25-29.

48. Lopes FP, de Azevedo MN, Marchiori E, da Fonseca LM, de Souza SA, Gutfilen B: Use of $99 \mathrm{mTC}$-anti-CD3 scintigraphy in the differential diagnosis of rheumatic diseases. Rheumatology (Oxford) 2010, 49:933-939.

49. Barrera $\mathrm{P}$, van der Laken $\mathrm{CJ}$, Boerman OC, Oyen WJ, van de Ven MT, van Lent PL, van de Putte LB, Corstens FH: Radiolabelled interleukin-1 receptor antagonist for detection of synovitis in patients with rheumatoid arthritis. Rheumatology (Oxford) 2000, 39:870-874.

50. Conti F, Priori R, Chimenti MS, Coari G, Annovazzi A, Valesini G, Signore A: Successful treatment with intraarticular infliximab for resistant knee monarthritis in a patient with spondylarthropathy: a role for scintigraphy with 99mTc-infliximab. Arthritis Rheum 2005, 52:1224-1226.

51. Barrera P, Oyen WJ, Boerman OC, van Riel PL: Scintigraphic detection of tumour necrosis factor in patients with rheumatoid arthritis. Ann Rheum Dis 2003, 62:825-828. 
52. Roimicher L, Lopes FP, de Souza SA, Mendes LF, Domingues RC, da Fonseca LM, Gutfilen B: (99 m)Tc-anti-TNF-alpha scintigraphy in RA: a comparison pilot study with MRI and clinical examination. Rheumatology (Oxford) 2011, 50:2044-2050.

53. Tran L, Huitema AD, van Rijswijk MH, Dinant HJ, Baars JW, Beijnen JH, Vogel W: CD20 antigen imaging with l-rituximab PET/CT in patients with rheumatoid arthritis. Hum Antibodies 2011, 20:29-35

54. Malviya G, Anzola KL, Podesta E, Lagana B, Del Mastro C, Dierckx RA, Scopinaro F, Signore A: (99 m)Tc-labeled rituximab for imaging B lymphocyte infiltration in inflammatory autoimmune disease patients. Mol Imaging Biol 2012, 14:637-646.

55. Miot-Noirault E, Perin F, Routledge L, Normier G, Le Pape A: Macrophage targeting with technetium-99 m labelled $J 001$ acylated poly-galactoside for scintigraphy of inflammation: optimization and assessment of imaging specificity in experimental arthritis. Eur J Nucl Med 1996, 23:61-68.

56. Vanhagen PM, Markusse HM, Lamberts SW, Kwekkeboom DJ, Reubi JC, Krenning EP: Somatostatin receptor imaging. The presence of somatostatin receptors in rheumatoid arthritis. Arthritis Rheum 1994, 37:1521-1527.

57. van der Laken CJ, Elzinga EH, Kropholler MA, Molthoff CF, van der Heijden JW, Maruyama K, Boellaard R, Dijkmans BA, Lammertsma AA, Voskuyl AE: Noninvasive imaging of macrophages in rheumatoid synovitis using 11C-(R)-PK11195 and positron emission tomography. Arthritis Rheum 2008, 58:3350-3355

58. Gent YY, Voskuyl AE, Kloet RW, van Schaardenburg D, Hoekstra OS, Dijkmans BA, Lammertsma AA, van der Laken CJ: Macrophage positron emission tomography imaging as a biomarker for preclinical rheumatoid arthritis: findings of a prospective pilot study. Arthritis Rheum 2012, 64:62-66.

59. Zinn KR, Chaudhuri TR, Smyth CA, Wu Q, Liu HG, Fleck M, Mountz JD, Mountz JM: Specific targeting of activated endothelium in rat adjuvant arthritis with a $99 \mathrm{mTc}$-radiolabeled E-selectin-binding peptide. Arthritis Rheum 1999, 42:641-649.

60. Jamar F, Houssiau FA, Devogelaer JP, Chapman PT, Haskard DO, Beaujean V, Beckers C, Manicourt DH, Peters AM: Scintigraphy using a technetium 99 m-labelled anti-E-selectin Fab fragment in rheumatoid arthritis. Rheumatology (Oxford) 2002, 41:53-61.

61. Gompels LL, Madden L, Lim NH, Inglis JJ, McConnell E, Vincent TL, Haskard $\mathrm{DO}$, Paleolog EM: In vivo fluorescence imaging of E-selectin: quantitative detection of endothelial activation in a mouse model of arthritis. Arthritis Rheum 2011, 63:107-117.

62. Post AM, Katsikis PD, Tait JF, Geaghan SM, Strauss HW, Blankenberg FG Imaging cell death with radiolabeled annexin $\mathrm{V}$ in an experimental model of rheumatoid arthritis. J Nucl Med 2002, 43:1359-1365.

63. Hansch A, Frey O, Sauner D, Hilger I, Haas M, Malich A, Brauer R, Kaiser WA In vivo imaging of experimental arthritis with near-infrared fluorescence. Arthritis Rheum 2004, 50:961-967.

64. Sugimoto K, Nishimoto N, Kishimoto T, Yoshizaki K, Nishimura T: Imaging of lesions in a murine rheumatoid arthritis model with a humanized antiinterleukin-6 receptor antibody. Ann Nucl Med 2005, 19:261-266.

65. Paulos CM, Turk MJ, Breur GJ, Low PS: Folate receptor-mediated targeting of therapeutic and imaging agents to activated macrophages in rheumatoid arthritis. Adv Drug Deliv Rev 2004, 56:1205-1217.

66. Turk MJ, Breur GJ, Widmer WR, Paulos CM, Xu LC, Grote LA, Low PS: Folatetargeted imaging of activated macrophages in rats with adjuvantinduced arthritis. Arthritis Rheum 2002, 46:1947-1955.

67. Matteson EL, Lowe VJ, Prendergast FG, Crowson CS, Moder KG, Morgenstern DE, Messmann RA, Low PS: Assessment of disease activity in rheumatoid arthritis using a novel folate targeted radiopharmaceutical Folatescan. Clin Exp Rheumatol 2009, 27:253-259.

68. Chen WT, Mahmood U, Weissleder R, Tung $\mathrm{CH}$ : Arthritis imaging using a near-infrared fluorescence folate-targeted probe. Arthritis Res Ther 2005, 7:R310-R317.

69. Gent YY, Weijers K, Molthoff CF, Windhorst AD, Huisman MC, Smith DE, Kularatne SA, Jansen G, Low PS, Lammertsma AA, van der Laken CJ: Evaluation of the novel folate receptor ligand [18 F]fluoro-PEG-folate for macrophage targeting in a rat model of arthritis. Arthritis Res Ther 2013, 15:R37.

70. Zheleznyak A, Wadas TJ, Sherman CD, Wilson JM, Kostenuik PJ, Weilbaecher $\mathrm{KN}$, Anderson CJ: Integrin alpha(v)beta as a PET imaging biomarker for osteoclast number in mouse models of negative and positive osteoclast regulation. Mol Imaging Biol 2012, 14:500-508.
71. Ryu JH, Lee A, Chu JU, Koo H, Ko CY, Kim HS, Yoon SY, Kim BS, Choi K, Kwon IC, Kim K, Youn I: Early diagnosis of arthritis in mice with collageninduced arthritis, using a fluorogenic matrix metalloproteinase 3-specific polymeric probe. Arthritis Rheum 2011, 63:3824-3832.

72. Put S, Schoonooghe S, Devoogdt N, Schurgers E, Avau A, Mitera T, D'Huyvetter M, De Baetselier P, Raes G, Lahoutte T, Matthys P: SPECT imaging of joint inflammation with nanobodies targeting the macrophage mannose receptor in a mouse model for rheumatoid arthritis. J Nucl Med 2013, 54:807-814.

73. Kinne RW, Becker W, Simon G, Paganelli G, Palombo-Kinne E, Wolski A, Bloch S, Schwarz A, Wolf F, Emmrich F: Joint uptake and body distribution of a technetium-99 m-labeled anti-rat-CD4 monoclonal antibody in rat adjuvant arthritis. J Nucl Med 1993, 34:92-98.

74. Kinne RW, Becker W, Koscheck T, Kuhlmann J, Sharkey RM, Behr T, PalomboKinne E, Goldenberg DM, Wolf F, Emmrich F: Rat adjuvant arthritis: imaging with technetium-99 m-anti-CD4 Fab' fragments. J Nucl Med 1995, 36:2268-2275.

75. Kneitz C, Wilhelm M, Tony HP: Improvement of refractory rheumatoid arthritis after depletion of B cells. Scand J Rheumatol 2004, 33:82-86.

76. Harrold LR, Reed GW, Kremer JM, Curtis JR, Solomon DH, Hochberg MC, Greenberg JD: The comparative effectiveness of abatacept versus anti-tumour necrosis factor switching for rheumatoid arthritis patients previously treated with an anti-tumour necrosis factor. Ann Rheum Dis 2014. Jan 29. doi: 10.1136/annrheumdis-2013-203936. [Epub ahead of print].

77. Finckh A, Ciurea A, Brulhart L, Moller B, Walker UA, Courvoisier D, Kyburz D, Dudler J, Gabay C: Which subgroup of patients with rheumatoid arthritis benefits from switching to rituximab versus alternative anti-tumour necrosis factor (TNF) agents after previous failure of an anti-TNF agent? Ann Rheum Dis 2010, 69:387-393.

78. Antony AC: Folate receptors. Annu Rev Nutr 1996, 16:501-521.

79. Nakashima-Matsushita N, Homma T, Yu S, Matsuda T, Sunahara N, Nakamura T, Tsukano M, Ratnam M, Matsuyama T: Selective expression of folate receptor beta and its possible role in methotrexate transport in synovial macrophages from patients with rheumatoid arthritis. Arthritis Rheum 1999, 42:1609-1616.

80. Henne WA, Rothenbuhler R, Ayala-Lopez W, Xia W, Varghese B, Low PS: Imaging sites of infection using a $99 \mathrm{mTc}$-labeled folate conjugate targeted to folate receptor positive macrophages. Mol Pharm 2012, 9:1435-1440.

81. Bilthariya U, Jain N, Rajoriya $V$, Jain AK: Folate-conjugated albumin nanoparticles for rheumatoid arthritis-targeted delivery of etoricoxib. Drug Dev Ind Pharm 2013. Oct 28. [Epub ahead of print].

82. Xia W, Hilgenbrink AR, Matteson EL, Lockwood MB, Cheng JX, Low PS: A functional folate receptor is induced during macrophage activation and can be used to target drugs to activated macrophages. Blood 2009, 113:438-446.

83. Gazi U, Martinez-Pomares L: Influence of the mannose receptor in host immune responses. Immunobiology 2009, 214:554-561.

84. Bullard DC, Hurley LA, Lorenzo I, Sly LM, Beaudet AL, Staite ND: Reduced susceptibility to collagen-induced arthritis in mice deficient in intercellular adhesion molecule-1. J Immunol 1996, 157:3153-3158.

85. Lee SI, Lee SY, Yoon KH, Choi KS, Jang KY, Yoo WH, Kim SH, Choi TH, Park JG: Molecular MR imaging for visualizing ICAM-1 expression in the inflamed synovium of collagen-induced arthritic mice. Korean J Radiol 2009, 10:472-480.

86. Firestein GS, Yeo M, Zvaifler NJ: Apoptosis in rheumatoid arthritis synovium. J Clin Invest 1995, 96:1631-1638.

87. Leibbrandt A, Penninger JM: RANK/RANKL: regulators of immune responses and bone physiology. Ann N Y Acad Sci 2008, 1143:123-150.

88. Choi Y, Arron JR, Townsend MJ: Promising bone-related therapeutic targets for rheumatoid arthritis. Nat Rev Rheumatol 2009, 5:543-548.

89. Cohen SB, Dore RK, Lane NE, Ory PA, Peterfy CG, Sharp JT, van der Heijde D, Zhou L, Tsuji W, Newmark R: Denosumab treatment effects on structural damage, bone mineral density, and bone turnover in rheumatoid arthritis: a twelve-month, multicenter, randomized, double-blind, placebo-controlled, phase II clinical trial. Arthritis Rheum 2008, 58:1299-1309.

90. Iranikhah M, Wilborn TW, Wensel TM, Ferrell JB: Denosumab for the prevention of skeletal-related events in patients with bone metastasis from solid tumor. Pharmacotherapy 2012, 32:274-284.

91. Atkins GJ, Kostakis P, Vincent C, Farrugia AN, Houchins JP, Findlay DM, Evdokiou A, Zannettino AC: RANK expression as a cell surface marker of 
human osteoclast precursors in peripheral blood, bone marrow, and giant cell tumors of bone. J Bone Miner Res 2006, 21:1339-1349.

92. Santini D, Perrone G, Roato I, Godio L, Pantano F, Grasso D, Russo A, Vincenzi B, Fratto ME, Sabbatini R, Della Pepa C, Porta C, Del Conte A, Schiavon G, Berruti A, Tomasino RM, Papotti M, Papapietro N, Onetti Muda A, Denaro V, Tonini G: Expression pattern of receptor activator of NFkappaB (RANK) in a series of primary solid tumors and related bone metastases. J Cell Physiol 2011, 226:780-784.

93. Ibrahim T, Sacanna E, Gaudio M, Mercatali L, Scarpi E, Zoli W, Serra P, Ricci R, Serra L, Kang Y, Amadori D: Role of RANK, RANKL, OPG, and CXCR4 tissue markers in predicting bone metastases in breast cancer patients. Clin Breast Cancer 2011, 11:369-375.

94. Zhang L, Teng Y, Zhang Y, Liu J, Xu L, Qu J, Hou K, Yang X, Liu Y, Qu X: Receptor activator for nuclear factor kappa $B$ expression predicts poor prognosis in breast cancer patients with bone metastasis but not in patients with visceral metastasis. J Clin Pathol 2012, 65:36-40.

95. Tak PP, Balanescu A, Tseluyko V, Bojin S, Drescher E, Dairaghi D, Miao S, Marchesin V, Jaen J, Schall TJ, Bekker P: Chemokine receptor CCR1 antagonist CCX354-C treatment for rheumatoid arthritis: CARAT-2, a randomised, placebo controlled clinical trial. Ann Rheum Dis 2013, 72:337-344.

96. Suzuki N, Nakajima A, Yoshino S, Matsushima K, Yagita H, Okumura K: Selective accumulation of CCR5+ T lymphocytes into inflamed joints of rheumatoid arthritis. Int Immunol 1999, 11:553-559.

97. Yang YF, Mukai T, Gao P, Yamaguchi N, Ono S, Iwaki H, Obika S, Imanishi T, Tsujimura T, Hamaoka T, Fujiwara H: A non-peptide CCR5 antagonist inhibits collagen-induced arthritis by modulating $T$ cell migration without affecting anti-collagen T cell responses. Eur J Immunol 2002, 32:2124-2132.

98. Okamoto H, Kamatani N: A CCR-5 antagonist inhibits the development of adjuvant arthritis in rats. Rheumatology (Oxford) 2006, 45:230-232.

99. Matsuyama T, Kitani A: The role of VCAM-1 molecule in the pathogenesis of rheumatoid synovitis. Hum Cell 1996, 9:187-192.

100. Lowin T, Straub RH: Integrins and their ligands in rheumatoid arthritis. Arthritis Res Ther 2011, 13:244.

101. Wilder RL: Integrin alpha V beta 3 as a target for treatment of rheumatoid arthritis and related rheumatic diseases. Ann Rheum Dis 2002, 61:ii96-ii99.

102. Faccio R, Takeshita S, Zallone A, Ross FP, Teitelbaum SL: c-Fms and the alphavbeta3 integrin collaborate during osteoclast differentiation. J Clin Invest 2003, 111:749-758.

103. Caporali F, Capecchi PL, Gamberucci A, Lazzerini PE, Pompella G, Natale M, Lorenzini S, Selvi E, Galeazzi M, Laghi Pasini F: Human rheumatoid synoviocytes express functional P2X7 receptors. J Mol Med (Berl) 2008, 86:937-949.

104. Labasi JM, Petrushova N, Donovan C, McCurdy S, Lira P, Payette MM, Brissette W, Wicks JR, Audoly L, Gabel CA: Absence of the P2X7 receptor alters leukocyte function and attenuates an inflammatory response. $\mathrm{J}$ Immunol 2002, 168:6436-6445.

105. Leung BP, Xu D, Culshaw S, McInnes IB, Liew FY: A novel therapy of murine collagen-induced arthritis with soluble T1/ST2. J Immuno/ 2004, 173:145-150.

106. Miyamoto H, Suzuki T, Miyauchi Y, Iwasaki R, Kobayashi T, Sato Y, Miyamoto K, Hoshi H, Hashimoto K, Yoshida S, Hao W, Mori T, Kanagawa H, Katsuyama E, Fujie A, Morioka H, Matsumoto M, Chiba K, Takeya M, Toyama Y, Miyamoto T: Osteoclast stimulatory transmembrane protein and dendritic cell-specific transmembrane protein cooperatively modulate cell-cell fusion to form osteoclasts and foreign body giant cells. J Bone Miner Res 2012, 27:1289-1297.
107. Chiu YH, Mensah KA, Schwarz EM, Ju Y, Takahata M, Feng C, McMahon LA, Hicks DG, Panepento B, Keng PC, Ritchlin CT: Regulation of human osteoclast development by dendritic cell-specific transmembrane protein (DC-STAMP). J Bone Miner Res 2012, 27:79-92.

108. Smolen JS, Aletaha D: Forget personalised medicine and focus on abating disease activity. Ann Rheum Dis 2013, 72:3-6.

10.1186/ar4542

Cite this article as: Put et al:: Molecular imaging of rheumatoid arthritis: emerging markers, tools, and techniques. Arthritis Research \& Therapy 2014, 16:208 